\title{
Correction to: Chemotherapy and targeted therapy for breast cancer patients with hepatitis $C$ virus infection
}

\author{
Soha Talima ${ }^{1}\left[\right.$ D Hebatallah Kassem ${ }^{2} \cdot$ Neemat Kassem $^{2}$
}

Published online: 21 September 2018

(c) The Japanese Breast Cancer Society 2018

\section{Correction to: Breast Cancer}

$$
\text { https://doi.org/10.1007/s12282-018-0904-2 }
$$

The correct name of the co-authors should be "Hebatallah Kassem" and "Neemat Kassem".

The original article has been corrected.

1 Clinical Oncology Department, Kasr Al-Ainy Center of Clinical Oncology and Nuclear Medicine (NEMROCK), Cairo University, 10 Koleat Al Tarbea Str. Haram, Cairo,

Egypt

2 Department of Clinical and Chemical Pathology, Kasr Al-Ainy Center of Clinical Oncology and Nuclear Medicine (NEMROCK), Cairo University, Cairo, Egypt 